\title{
Rationalization of cooling water consumption in extraction system B-811 LSV
}

\author{
Sandra Budžaki ${ }^{1}$, F. Čačić ${ }^{1 *}$, G. Miljić \\ Josip Juraj Strossmayer University of Osijek, Faculty of Food Technology Osijek, Franje Kuhaca 20, HR-31000 Osijek, Croatia \\ professional paper
}

\begin{abstract}
Summary
Water (drinkable) is vital natural resource, and during the last few decades it is imperative to reduce its needless consumption. Extraction devices are known for their significant cooling water consumption and laboratory scale devices mainly use drinkable water. Aim of this paper was rationalization of cooling water consumption during extractions in universal extraction system B-811 LSV by recirculating cooling water trough cooling tower. In order to obtain the data for cooling tower design, measurements of cooling water flow, inlet and outlet cooling water temperatures, air humidity and temperature were conducted. Design of cooling tower based on obtained values resulted in cylindrical cooling tower, $81.45 \mathrm{~cm}$ height and with base radius of $13.96 \mathrm{~cm}$. Cooling water consumption was reduced $56.87 \%$.
\end{abstract}

Keywords: rationalization, cooling water, extraction, cooling tower

\section{Introduction}

Cooling water has major roll in today's industry as medium for heat removal from technology processes (Bhatia, 2009). Refineries, power plants, gas turbines, nuclear reactors and similar facilities consume significant amounts of cooling water during their normal operation. Unfortunately, quantity of water available in nature, which is used for cooling a flow of individual stages of the process, is limited and expensive. For this reason, usage of cooling towers as auxiliary plant is recommended. Cooling towers are ancillary industrial units, in which the heated cooling water is cooled by ambient air and returned to the process (BEE, 2005).

Cooling towers are employed in situations where cooling water is needed in large amounts, with aim to rationalize consumption (Cavalcante et al., 2013; Almató et al., 1997; Thevendiraraj et al., 2003; Pombo et al., 2013). Rationalisation in cooling water consumption varies from $23 \%$ to $50 \%$ and depends on process setup.

As same as the industrial plants, many laboratory scale devices require substantial amounts of water for cooling the individual process stages during their operation. One such device is a universal extraction system B-811 LSV (BÜCHI, Switzerland). During normal operation of device, by measuring the flow of cooling water through the condenser unit, it was found that device uses substantial amount of cooling water (in this case drinkable water). For this reason, the purpose of this research was rationalization of cooling water consumption in the universal extraction system by introducing cooling tower as auxiliary unit for recycling cooling water.

\section{Material and methods}

Cooling tower design and dimensions were done by measurement of inlet and outlet temperatures of cooling water, flow rate of cooling water and relative air temperature and humidity. Based on these parameters calculations were made to determine size and shape of cooling tower as well as the cooling water consumption in case of its use in comparison to consumption without it.

Extraction system B-811 LSV has four independent extraction units and four different Soxhlet extraction methods can be performed in each of them: standard, warm, hot and continuous. Each of extraction methods differs in conditions and parameters. All methods are conducted in three steps: extraction, rinsing and drying. Schematic cross section of one extraction unit is show in Fig. 1.

Inlet and outlet temperatures in four condenser units of extraction system B-811 LSV were measured by type $\mathrm{T}$ thermocouple probes (Cole-Parmer International, USA). Thermocouple probes are designed to measure temperatures in range from $-250{ }^{\circ} \mathrm{C}$ to $404{ }^{\circ} \mathrm{C}$ with time constant of 0.15 seconds, coated with PTFE $\left(\right.$ Teflon $^{\mathrm{TM}}$ ) and have non isolated tip with $0.0254 \mathrm{~cm}$ in diameter. In temperature range from $0{ }^{\circ} \mathrm{C}$ to $200^{\circ} \mathrm{C}$ they have accuracy of $0.8{ }^{\circ} \mathrm{C}$ or $0.4 \%$ measurement range. They are suited for use in lightly oxidising or reducing environments and with high water content (Cole-Parmer International, 2014). 


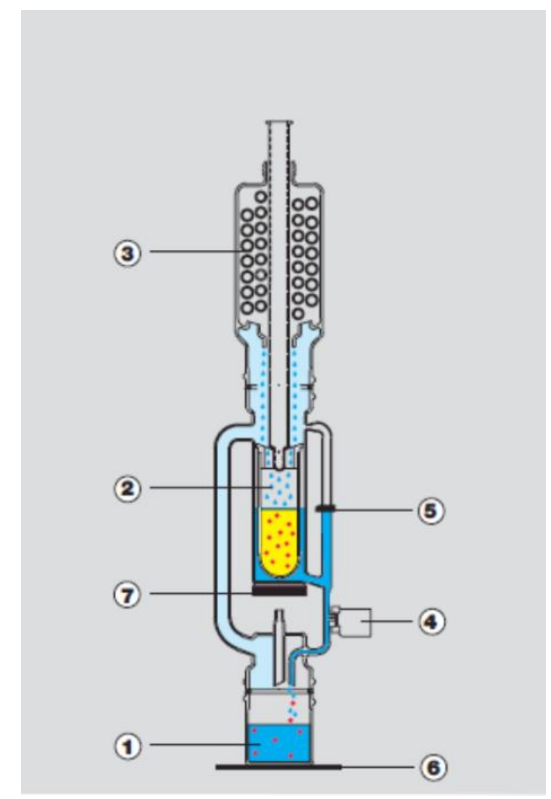

Fig. 1. Single extraction unit of extraction system B-811 LSV (BÜCHI, Switzerland). 1 - solvent container, 2 - extraction sleeve, 3 - condensation tube, 4 - glass valve, 5 - adjustable optical sensor,

6 - lower heater, 7 - upper heater

Thermocouple probes were connected to custom designed six channel amplifier, based on OP07 operational amplifier integral circuits, for signal amplification ( $\mathrm{mV}$ range to $\mathrm{V}$ range) prior analog to digital conversion. Conversion of analog signals from thermocouple probes to digital signals was done by 8 channel A/D converter PICO ADC-16, and logged on PC with use of program for data acquisition
PicoLog(PICO Technology, UK). ADC-16 analog to digital converter has sampling rate of 1.5 samples per second with $0.2 \%$ conversion error, operational temperature range from $0{ }^{\circ} \mathrm{C}$ to $70{ }^{\circ} \mathrm{C}$. During measurements ambient temperature was constant $20^{\circ} \mathrm{C}$, so according to manufacturer specifications there was no need for temperature compensation on recorded results. Measurement setup is shown in Fig. 2.

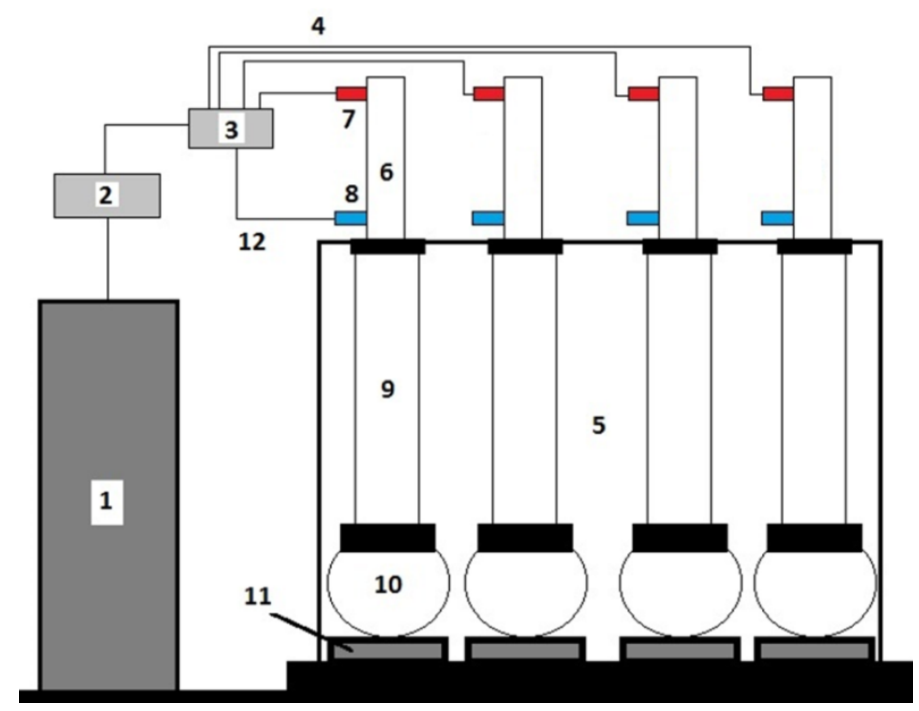

Fig. 2. Cooling water temperature measurement setup in extraction system B-811 LSV (BÜCHI, Switzerland). 1 - PC 486, 80 MHz, 2 - PICO ADC-16, 3 - signal amplifier, 4 -T type thermocouples condenser outlet temperature, 5 - universal extraction device B-811 LSV, 6-condensers,

7 - cooling water outlet, 8 - cooling water inlet, 9 - extraction sleeve,

10 - solvent container, 11 - heater, 12 - T type thermocouple condenser inlet. 
Volume flow of cooling water, $F_{w, v o l}\left[\mathrm{~m}^{3} / \mathrm{h}\right]$ was determined as ratio of time $[\mathrm{s}]$ required to fill predetermined $(1 \mathrm{~L})$ volume in graduated vessel, volume/time. Relative humidity $\phi[\%]$ and temperature of laboratory air were measured by digital sensor DHT-11 (D-Robotics, United Kingdom), which can operate in temperature range from $0{ }^{\circ} \mathrm{C}$ to $50^{\circ} \mathrm{C}$ with accuracy of $1{ }^{\circ} \mathrm{C}$ and relative humidity range from $20 \%$ to $90 \%$ with accuracy of $4 \%$.

\section{Results and discussion}

Inlet and outlet cooling water temperature measurements were conducted during the extraction of polyphenols and flavonoids from different cereals using different methods of extraction (standard and hot three times, warm and continuous extraction four times). Cumulative extraction time of performed operations was 950 minutes, and based on the measured value of cooling water flow which was $65.46 \mathrm{~L} / \mathrm{h}$ total of 1036.35 litres of cooling water was calculated.

Temperature measurements of cooling water (Fig. 3) showed that lowest inlet temperature of cooling water during the whole extraction period was $20.2{ }^{\circ} \mathrm{C}$, while maximum outlet temperature was $41.9^{\circ} \mathrm{C}$.

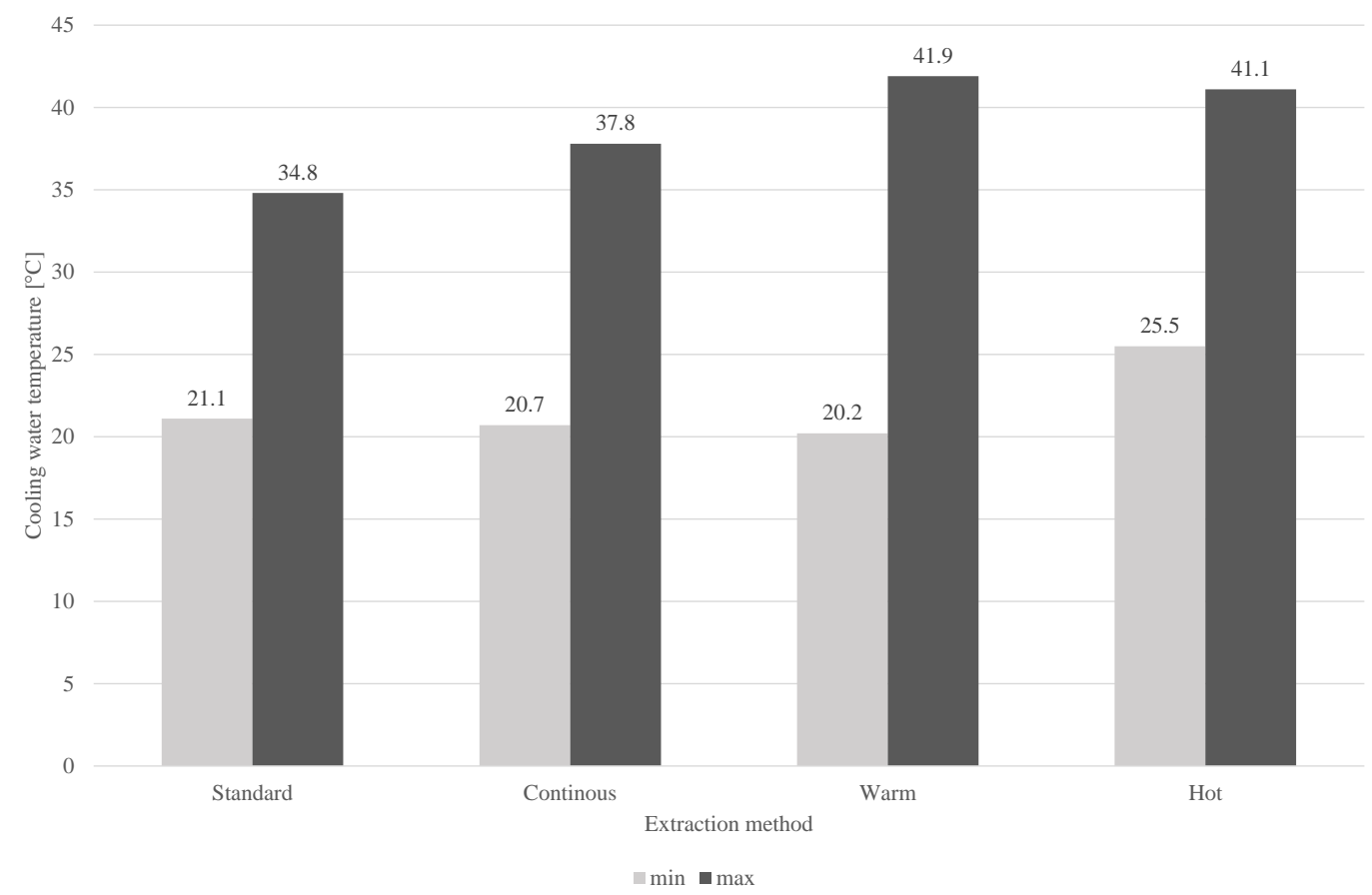

Fig. 3. Minimum (inlet) and maximum (outlet) measured temperatures of inlet and outlet cooling water for four different methods of extraction in device B-811 LSV

These temperatures are essential for cooling tower design because their difference presents cooling effect that needs to be accomplished in cooling tower (Goyal, 2012).

During measurements average relative humidity of laboratory air was $40 \%$, and average air temperature was $20^{\circ} \mathrm{C}$.

All parameters obtained by measurements during the extraction procedures performed without the cooling tower are shown in the Table 1 and used in the further procedure for cooling tower design.

Table 1. Measured parameters needed for cooling tower design

\begin{tabular}{|l|c|}
\hline Parameters & Values \\
\hline Inlet cooling water temperature, $t_{w, i}$ & $20^{\circ} \mathrm{C}$ \\
\hline Outlet cooling water temperature, $t_{w, o}$ & $42{ }^{\circ} \mathrm{C}$ \\
\hline Temperature difference, $\Delta t_{w}=t_{w, i}-t_{w, o}$ & $2{ }^{\circ} \mathrm{C}$ \\
\hline Laboratory air temperature, $t_{a}$ & $20^{\circ} \mathrm{C}$ \\
\hline Relative air humidity, $\phi$ & $40 \%$ \\
\hline Cooling water volume flow, $F_{w, v o l}$ & $1.0909 \mathrm{~L} / \mathrm{min}\left(0.065454 \mathrm{~m}^{3} / \mathrm{h}\right)$ \\
\hline Total runtime of B-811 LSV device, $\tau_{\text {tot }}$ & $950 \mathrm{~min}$ \\
\hline Consumed cooling water, $V_{\text {tot }}$ & $1036.35 \mathrm{~L}$ \\
\hline
\end{tabular}


Cooling tower design calculations were done according to procedure described by Beer (2014). Originally, hyperbolic cooling tower dimensions were calculated, but due to the simplifications of manufacturing process in laboratory scale, recalculation was done for cylindrically shaped cooling tower with same cooling effect as hyperbolical (Fig. 4).

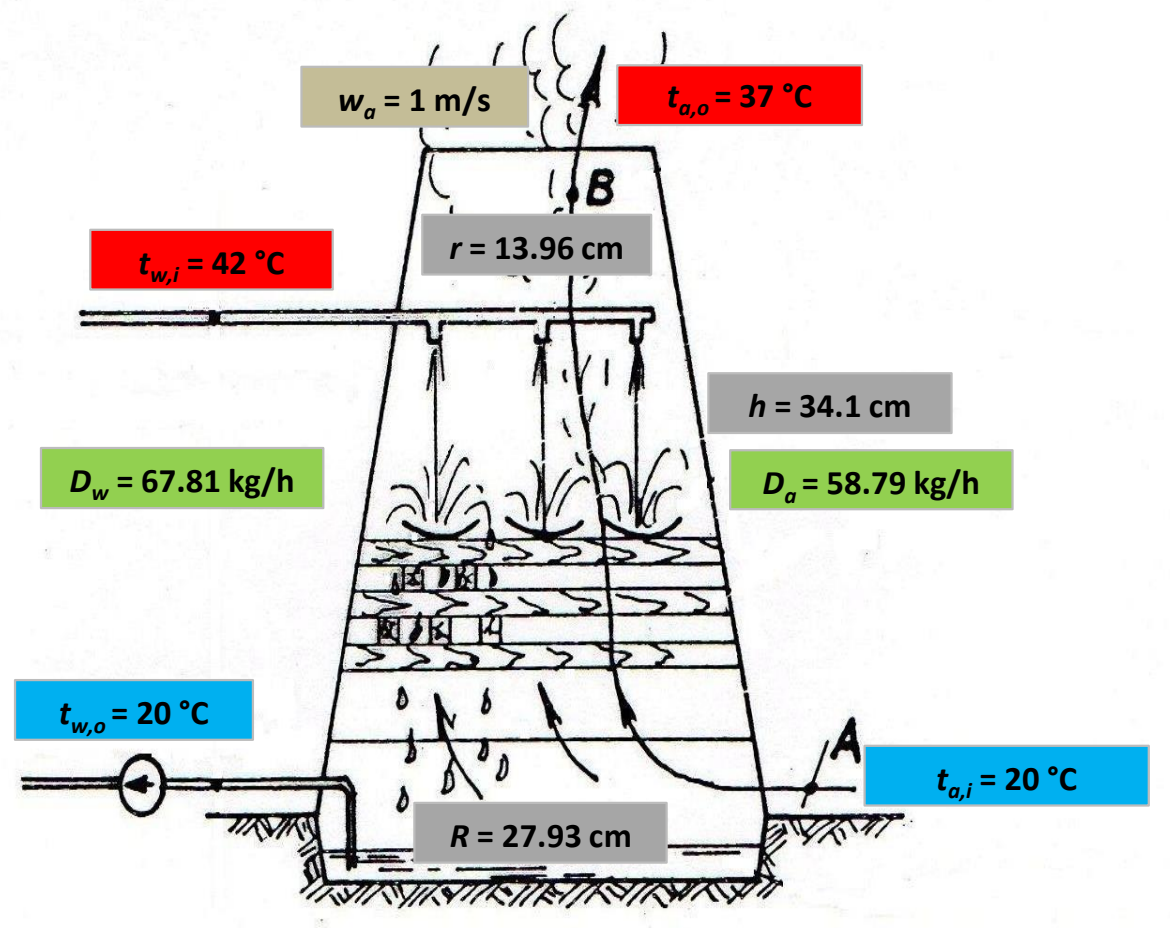

Fig. 4. Calculated dimensions and working parameters of cooling tower $t_{w, i}$-inlet water temperature, $t_{w, o}$ - outlet water temperature (cooled), $D_{w}$ - mass flow of cooling water, $D_{a}$ - mass flow of air, $t_{a, i}$ - inlet air temperature, $t_{a, o}-$ outlet air temperature, $w_{a}$ - air velocity, $h$-cooling tower height, $r$-cooling tower top diameter, $R$ - cooling tower base diameter

First step in recalculation was to determine volume of hyperbolic cooling tower from equation for volume of truncated cone:

$$
V_{t c}=\left(\frac{\pi \cdot h}{3}\right) \cdot\left(R^{2}+r^{2}+R \cdot r\right)\left[\mathrm{cm}^{3}\right](1)
$$

where is:

$V_{t c}$ - volume of truncated cone $\left[\mathrm{cm}^{3}\right]$,

$h$ - height of cooling tower $[\mathrm{cm}]$,

$R$ - cooling tower base diameter $[\mathrm{cm}]$,

$r$ - cooling tower top diameter $[\mathrm{cm}]$.

By including values for hyperbolical cooling tower in Eq. 1, obtained volume of dimensioned hyperbolical tower was $12466.384 \mathrm{~cm}^{3}$. Next from equation for volume of cylinder (Eq. 2), by assuming that cylinder has same volume as truncated cone (cooling tower) and diameter equal to top diameter of cooling tower, height of cylinder can be calculated.

$$
V_{c}=r_{c}^{2} \cdot \pi \cdot h_{c}\left[\mathrm{~cm}^{3}\right]
$$

where is:

$V_{c}-$ cylinder volume $\left[\mathrm{cm}^{3}\right]$,

$r_{c}$ - base radius of cylinder (top radius of hyperbolic cooling tower) $[\mathrm{cm}]$,

$h_{c}$ - cylinder height $[\mathrm{cm}]$.

Height of cylindrical cooling tower, $h_{c}$, calculated from Eq. 2 was $81.45 \mathrm{~cm}$. Dimensions of cylindrical cooling tower are shown in Fig. 5. 


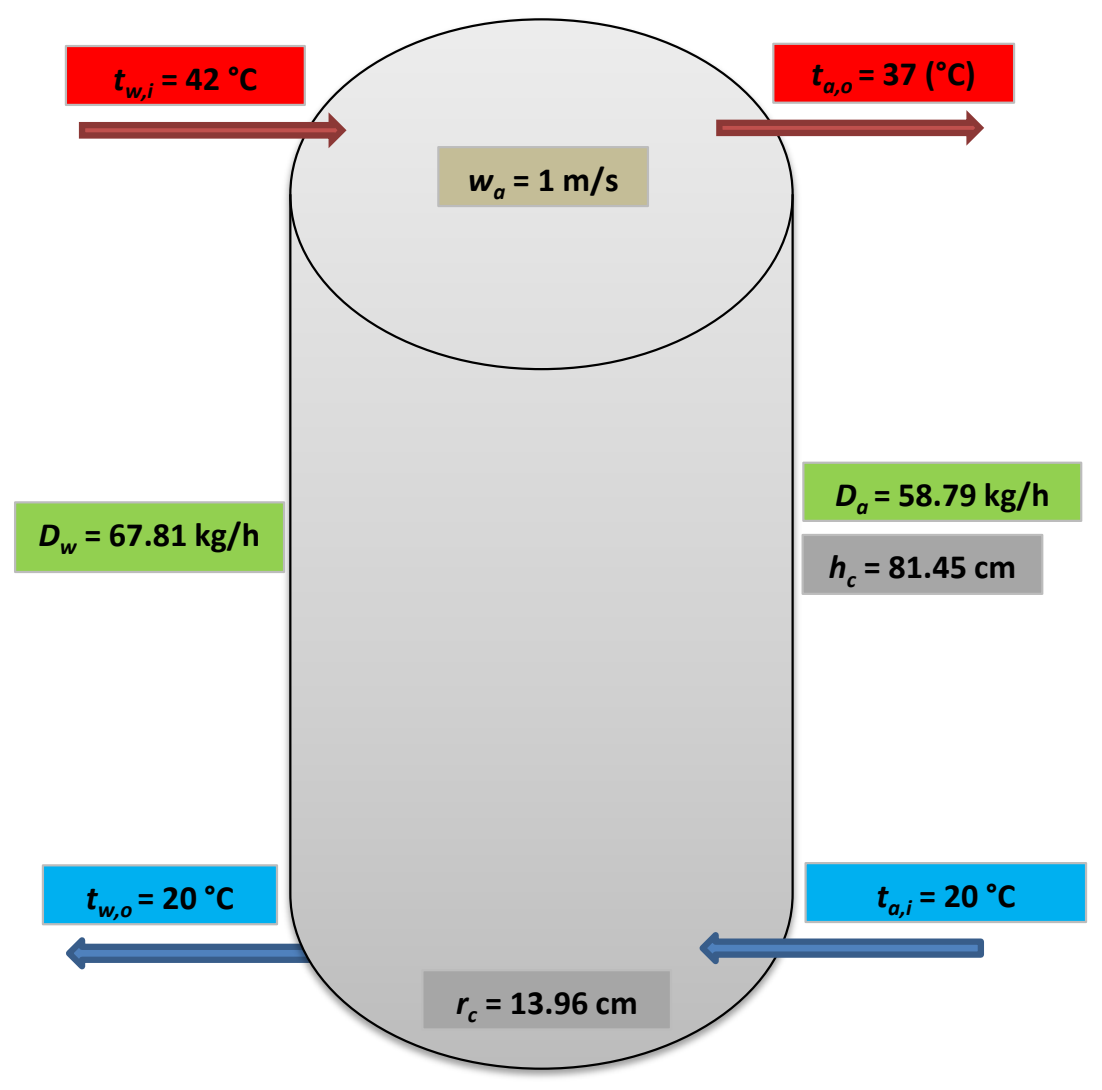

Fig. 5. Calculated dimensions and working parameters of cooling tower $t_{w, i}$-inlet water temperature, $t_{w, o}$ - outlet water temperature (cooled), $D_{w}$ - mass flow of cooling water, $D_{a}$ - mass flow of air, $t_{a, i}$-inlet air temperature, $t_{a, o}-$ outlet air temperature, $w_{a}-$ air velocity, $h_{c}-$ cooling tower height, $r_{c}$ - cooling tower base diameter

Overall water consumption in cooling tower also includes water needed for desalting. Volume of cooling water tank $(120 \mathrm{~L})$ has been chosen as two times the volume flow of cooling water trough device in one hour of operation. Total cooling water consumption of device, in 950 minute runtime, can be calculated from Eq. 3 .

$$
V_{c w, t o t}=V_{t}+\left(F_{w, d e s} \cdot 1000 \cdot \frac{\tau}{60}\right)[\mathbf{L}]
$$

where is:

$V_{c w, t o t}$ - total cooling water consumption in cooling tower [L],

$V_{t}$ - cooling water tank volume [L],

$\tau$-runtime [min],

$F_{w, d e s}$ - desalting water volume per hour of operation $\left[\mathrm{m}^{3} / \mathrm{h}\right]$.
Total water consumption in cylindrical cooling tower calculated (Eq. 3) is $446.96 \mathrm{~L}$.

Rationalization of cooling water consumption can be calculated from Eq. 4:

$$
\boldsymbol{V}=\boldsymbol{V}_{\text {tot }}-\boldsymbol{V}_{c w, t o t}[\mathbf{L}]
$$

where is:

$V$ - savings in cooling water consumption [L],

$V_{\text {tot }}$ - cooling water consumption in B-811 LSV [L],

$V_{c w, t o t}$ - cooling water consumption with cooling tower [L].

Rationalization in cooling water consumption calculated from Eq. 4 is 589.39 L. Consumption of cooling water with and without cooling tower is show in Fig. 6. 


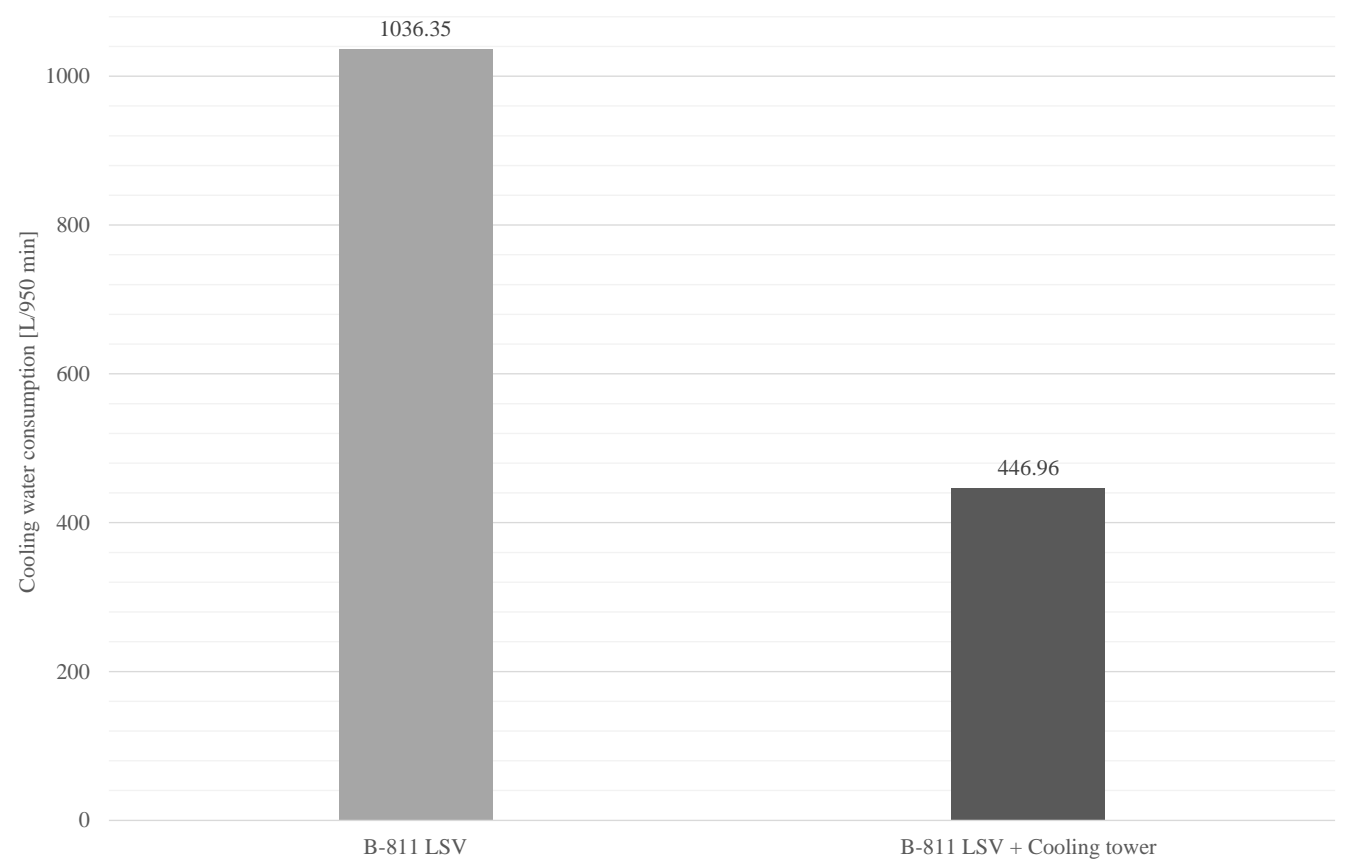

Fig. 6. Comparison of cooling water consumption (during $950 \mathrm{~min}$ ) with and without cooling tower

In order to verify design calculation of cylindrical cooling tower two computer applications were created in free web based application, frontend for Python programming language, CodeSkulptor development environment (Rice University in Huston, Texas, USA). First application requires input of cooling water flow $(\mathrm{L} / \mathrm{min})$, inlet water temperature in cooling tower $\left({ }^{\circ} \mathrm{C}\right)$, outlet cooling water temperature from cooling tower $\left({ }^{\circ} \mathrm{C}\right)$ and relative humidity of air $(\%)$. After input of all parameters, application calculates all remaining values of cylindrical cooling tower and prints them onscreen.

Second application has programmed dimensions and parameters of cylindrical cooling tower (based on prior calculations), user inputs inlet water temperature and applications calculates all other values of cylindrical cooling tower.

Obtained dimensions of cylindrical cooling tower $(81.45 \mathrm{~cm}$ height with $13.96 \mathrm{~cm}$ diameter) are suitable for laboratory installation. Cooling water and air are in direct contact, with forced air countercurrent flow, which improves cooling effects as previously described by Guzović (1996). Cooling water consumption with application of cooling tower is $446.96 \mathrm{~L}$ during 950 minutes of extraction time, which presents significant reduction in cooling water consumption $(56.85 \%)$. Electrical consumption of cooling water pump and ventilator is negligible and therefore it is not taken into account. Reason for this is predicted consumption of $300 \mathrm{~W}$ in 15 hours of operation, which can be supported by very low flows of cooling water and air.
Cooling tower efficiency can be improved in different ways, by employing tower filler which increases contact surface for heat exchange between water and air (Capehart, 2007), or by using cooling water with less hardness which would result in decrease of desalination water need. High concentration of salts in cooling water results in faster deposition of salts on heat exchanger walls which adds extra thermal resistance and lowers efficiency of heat exchange. Based on data for water hardness in Osijek region, concentration of salt $\left(\mathrm{CaCO}_{3}\right)$ was estimated to be high $(294.6 \mathrm{mg} / \mathrm{L})$. Efficiency of cooling tower can be even greater than calculation shows, because according to theory cooling water can be cooled down to wet bulb temperature of air (Prelec, 1994), while this paper assumes ambient temperature as lowest possible. Additional care should be taken for removing wet air exiting from cooling tower from closed space (laboratory), because of increase in laboratory air humidity would lower efficiency of cooling tower.

\section{Conclusions}

Results of this study show that rationalization in cooling water consumption in universal extraction system B-811 LSV is possible by usage of dimensioned laboratory scaled cooling tower for reuse of cooling water in semi-closed cooling system. Results indicate reduction of cooling water consumption of $56.87 \%$. Besides possible economic 
benefits, this solution is also environmentally friendly because closed cooling system prevents unnecessary loss of drinkable water which is used as cooling water.

\section{List of symbols}

$D_{a}-$ mass flow of air $[\mathrm{kg} / \mathrm{h}]$

$D_{w}$ - mass flow water $[\mathrm{kg} / \mathrm{h}]$

$F_{w, d e s}-$ desalting water volume per hour of operation $\left[\mathrm{m}^{3} / \mathrm{h}\right]$

$F_{w, v o l}-$ Volume flow of cooling water $\left[\mathrm{m}^{3} / \mathrm{h}\right]$

$\phi$ - Relative humidity [\%]

$h$ - height of cooling tower [cm]

$h_{c}-$ cylinder height $[\mathrm{cm}]$

$r$ - cooling tower top diameter $[\mathrm{cm}]$

$r_{c}$ - base radius of cylinder (top radius of hyperbolic cooling tower) $[\mathrm{cm}]$

$R$ - cooling tower base diameter $[\mathrm{cm}]$

$t_{a, i}-$ inlet air temperature

$t_{a, o}$ - outlet air temperature

$t_{w, i}-$ inlet water temperature

$t_{w, o}-$ outlet water temperature

$\tau$ - runtime [min]

$V$ - savings in cooling water consumption [L]

$V_{c}$ - cylinder volume $\left[\mathrm{cm}^{3}\right]$

$V_{c w, t o t}$ - cooling water consumption with cooling tower [L]

$V_{t}-$ cooling water tank volume [L]

$V_{t c}-$ volume of truncated cone $\left[\mathrm{cm}^{3}\right]$

$V_{\text {tot }}-$ cooling water consumption in B-811 LSV [L]

\section{References}

Almato, M., Sanmartí, E., Espuna, A., Puigjaner, L. (1997): Rationalizing the water use in the batch process industry, Comput. Chem. Eng. 21 (Suppl. 1), S971-S976.
Beer E: Priručnik za dimenzioniranje uređaja kemijske procesne industrije. HDKI/Kemija u industriji, Zagreb, 1994.

Bhatia A: Cooling water problems and solutions. Continuing Education and Development, Inc. New York, USA, 2009.

Bureau of Energy Efficiency (BEE): Energy efficiency in electrical utilities, Second edition. Ministry of Power, New Delhi, India, 2005. http://www.emtindia.net/Book3/Book3.htm [19.1.2014.]

Cavalcante, L.M., Machado, L.C.G.T., de Lima, A.M.M. (2013): Evaluation of the environmental performance and rationing of water consumption in industrial production of beverages, Rev. Ambient. Agua. 8 (3), 191-202.

Capehart BL: Encyclopedia of Energy Engineering and Technology. CRC Press, Taylor and Francis Group, USA, 2007.

Goyal J: Effective Thermal Design Of Cooling Towers. Air Liquide Engineering and Construction, Lurgi India, 2012.

Guzović Z: Izmjenjivači topline u termoenergetskim postrojenjima., Zavod za energetska postrojenja, Katedra za turbostrojeve, Fakultet strojarstva i brodogradnje Sveučilište u Zagrebu, Zagreb, 1996.

Pombo, F.R., Magrini, A., Szklo, A. (2013): An analysis of water management in Brazilian petroleum refineries using rationalization techniques, Resour. Conserv. Recy. 73, 172-179.

Prelec Z: Energetika u procesnoj industriji. Školska knjiga, Zagreb, 1994.

Thevendiraraj, S., Klemes, J., Paz, D., Aso, G., Cardenas, G.J. (2003): Water and wastewater minimisation study of a citrus plant, Resour. Conserv. Recy. 37, 227-250.

Received: October 10, 2014

Accepted: December 15, 2014 